\title{
POTREBE I ZADOVOLJSTVO KORISNIKA BIBLIOBUSA GRADSKE KNJIŽNICE ZADAR
}

\author{
MOBILE LIBRARY ZADAR USERS' \\ NEEDS AND SATISFACTION
}

\author{
Marko Pavlović \\ Odjel za informacijske znanosti \\ Sveučilište u Zadru \\ mpavlovic171@gmail.com \\ Mate Juric \\ Odjel za informacijske znanosti \\ Sveučilište u Zadru \\ mjuric@unizd.hr
}

UDK / UDC 021.65:028:001.102-047.24(497.5 Zadar)

Izvorni znanstveni rad / Original scientific paper

Primljeno / Received: 31. 8. 2020.

Prihvaćeno / Accepted: 5. 11. 2020.

\section{Sažetak ${ }^{1}$}

Cilj. Cilj ovog istraživanja bio je utvrditi informacijske potrebe i čitateljske navike korisnika bibliobusa Gradske knjižnice Zadar te njihovo zadovoljstvo postojećim uslugama i izborom građe koju nudi bibliobusna služba. Svrha je bila prikupiti povratne informacije korisnika kako bi se podržao nastavak usluga koje su korisnicima važne, uz moguća daljnja unaprjeđenja usluga.

Pristup/metodologija/dizajn. Anketirano je 100 korisnika bibliobusa svih dobnih skupina tijekom ljeta 2019. godine te su provedena dva intervjua s informatorima tije-

\footnotetext{
1 Članak je nastao na temelju diplomskog rada studenta Marka Pavlovića pod naslovom Informacijske potrebe korisnika bibliobusa Gradske knjižnice Zadar, napisanog pod mentorskim vodstvom Mate Jurica i predstavlja njegovu prerađenu verziju koja obuhvaća i rezultate naknadno provedenih intervjua. Rad je obranjen na Sveučilištu u Zadru 20. siječnja 2020. godine.
}

Vjesnik bibliotekara Hrvatske 63, 1-2(2020), 309-336 ISSN 0507-1925 
kom ljeta 2020. godine. Uzorkom su obuhvaćeni korisnici s otoka i priobalnih područja koje obilazi bibliobus 2 Gradske knjižnice Zadar.

Rezultati. Dvije su glavne skupine korisnika bibliobusa: učenici i odrasle osobe. Učenici više posuđuju multimediju, zabavne i knjige o sportu te čitaju dječje knjige, dok odrasli više posuđuju beletristiku i publicistiku. Zaposlene osobe i umirovljenici uglavnom su zadovoljni izborom knjiga, dok su učenici izrazito zadovoljni. Korisnici su izrazito zadovoljni uslugama knjižničara - informatora. Informatori prilagođavaju preporuke i dostupnost građe jer dobro poznaju potrebe većinom redovitih korisnika.

Ograničenja. Uzorkom nije obuhvaćen bibliobus 1 koji u većoj mjeri obilazi kopneni dio Zadarske županije. Istraživanje je provedeno tijekom ljeta, a velik je broj stajališta bibliobusa uz škole koje su u tom razdoblju prazne.

Praktična primjena. Unaprjeđenje i proširenje građe i usluga može se provesti na temelju prijedloga korisnika i podataka o razinama zadovoljstva pojedinim uslugama.

Društveni značaj. Uvid u potrebe korisnika knjižnica u ruralnim područjima omogućuje nastavak brige za izjednačavanjem pristupa informacijama u ruralnim i urbanim područjima. Visoko zadovoljstvo korisnika potvrđuje nezamjenjivu ulogu bibliobusa Gradske knjižnice Zadar po pitanju pružanja usluga u županijskim naseljima koja nemaju stacioniranu knjižnicu.

Originalnost/vrijednost. S obzirom na to da u Hrvatskoj ima malo sličnih istraživanja vezano za pokretne knjižnice, metodologija i rezultati rada mogu poslužiti i drugim bibliobusnim službama kao primjer dobre prakse, za ispitivanje potreba i zadovoljstva korisnika s ciljem unaprjeđenja rada službi.

Ključne riječi: bibliobusna služba, Gradska knjižnica Zadar, korisničke potrebe, narodna knjižnica, pokretna knjižnica

\begin{abstract}
Purpose. The aim of this research was to determine the information needs and reading habits of the users of the mobile library services of the Zadar Public Library, as well as their satisfaction with the existing services and the choice of library materials available at the mobile library service. The purpose was to gather user feedback in order to support the continuation of the services that are important to the users, with the possible further service improvements.

Approach/methodology/design. The research included a questionnaire that was distributed to 100 mobile library users of all ages during the summer of 2019, and two interviews with the information services librarians that were conducted during the summer of 2020. The sample included the users from the islands and coastal areas that are served by the mobile library no. 2 from the Zadar City Library.
\end{abstract}


Findings. Pupils and adults are the two main groups of mobile library users. The pupils borrow more multimedia, entertainment, and sports books, and they read children's books, while the adults borrow more fiction and non-fiction books. The adult users, who are employed or retired, stated that they were mostly satisfied with the choice of books, while the pupils were completely satisfied. The users were completely satisfied with the information services librarians. These librarians take care of user recommendations and availability of library materials because they are well aware of the needs of the regular library members.

Research limitations. The sample did not include the mobile library service no. 1, which serves mainly the inland of the Zadar County. The research was conducted during the summer, and most of the mobile library stops that are next to the schools were empty because of the summer holidays.

Practical implications. Further improvement of library services and acquisition of new library materials can be carried out on the basis of the user suggestions and their satisfaction with the availability of library materials.

Social implications. An insight into the needs of the mobile library users in rural areas enables further work on equalizing access to information in both rural and urban areas. The high user satisfaction confirms the irreplaceable role of the Zadar Public Library mobile library service in the county settlements that do not have stationary libraries.

Originality/value. Considering that there are very few similar surveys in Croatia related to mobile libraries, the methodology and the results of the work can serve other mobile library services as an example of good practice when they wish to examine the needs and satisfaction of users in order to improve the services.

Keywords: mobile library, mobile library service, public library, user needs, Zadar Public Library

\section{Uvod}

Bibliobusi, kao najpoznatiji oblik pokretnih knjižnica, imaju nezamjenjivu ulogu u pružanju pristupa knjižničnim uslugama u udaljenim ruralnim područjima. Stanovnici ruralnih područja povremeno dolaze u županijska središta u kojima se nalaze narodne knjižnice i njihovi ogranci. Međutim, učestalost takvih posjeta nije dovoljna i vremenski je ograničena, što doprinosi otežanom pristupu knjižničnim uslugama. Zbog toga su između ostalog potrebne usluge mobilnih knjižnica. Ovim radom nastoji se istražiti kakve su informacijske i čitateljske potrebe korisnika bibliobusa Gradske knjižnice Zadar, koliko je njihovo zadovoljstvo postojećim uslugama i imaju li prijedloge za unaprjeđenje usluga. 
U Standardima za narodne knjižnice ${ }^{2}$ iz 1999. godine obuhvaćeni su Standardi za pokretne knjižnice - bibliobuse. Definirani su oblici i način rada bibliobusa, kao i samo uređenje bibliobusa koji kao jedan od oblika pokretne knjižnice ima glavnu zadaću opskrbljivati korisnike knjigama, časopisima i drugim izvorima informacija, koji žive u gradskim četvrtima, prigradskim i seoskim naseljima, odnosno, ondje gdje nema osnovnih uvjeta za druge oblike djelovanja narodne knjižnice. ${ }^{3}$

Standardima se navodi kako bibliobusi ne bi trebali služiti isključivo za posudbu knjiga. Bibliobusna služba određene narodne knjižnice treba prepoznati i druge potrebe korisnika i organizirati razna događanja kao što su npr. radionice, predstave, gostovanja pisaca, predavanja, izložbe i sl. Nadalje, Standardima je utvrđeno da korisnici bibliobusa imaju pravo biti i članovi određene središnje narodne knjižnice. Narodna knjižnica (bibliobusna služba) sama odlučuje o ustroju i načinu rada s obzirom na opseg posla, o oblikovanju knjižničnog fonda i o prostoru (mjestima) gdje je potrebno djelovati. Nadalje, ukupni fond knjižnične građe bibliobusa treba biti tri puta veći od kapaciteta, od toga $50 \%$ otpada na beletristi$\mathrm{ku}, 30 \%$ na literaturu za djecu, $20 \%$ na popularno-znanstvenu literaturu, a manji dio postotka odnosi se na časopise i priručnu literaturu. Također, knjižnični fond bibliobusa mora sadržavati knjige koje obrađuju aktualne teme te je fond potrebno s vremena na vrijeme popunjavati. Zanimljivo je istaknuti kako se Standardima iz 1999. godine ne preporučuje u bibliobusu posjedovati AV građu zbog temperaturnih razlika. ${ }^{4}$

\section{IFLA-ine Smjernice za pokretne knjižnice}

Prvo izdanje IFLA-inih Smjernica za pokretne knjižnice datira još iz davne 1991. godine, a Standardi za narodne knjižnice u Republici Hrvatskoj, sa Standardima za pokretne knjižnice - bibliobuse objavljeni su 1999. godine. Prerađeno izdanje IFLA-inih Smjernica za pokretne knjižnice iz 2010. godine donosi nekoliko promjena u odnosu na spomenuta izdanja.

\subsection{Vrste pokretnih knjižnica}

Pokretne knjižnice uz stacionirane knjižnice najčešći su način djelovanja pokretne knjižnice. Središte područja po svojoj djelatnosti obuhvaća središnju knjižnicu koja svojim korisnicima omogućuje uslugu pokretne knjižnice u udaljenim naseljima i rubnim dijelovima grada, odnosno primarno je namijenjena za naselja

\footnotetext{
2 Usp. Standardi za narodne knjižnice u Republici Hrvatskoj. // Narodne novine 58, 1071(1999). [citirano: 2019-09-22]. Dostupno na: https://narodne-novine.nn.hr/clanci/sluzbeni/1999_06_58_1071.html

3 Usp. isto.

4 Usp. isto.
} 
koja nemaju uvjete za stacioniranu knjižnicu. ${ }^{5}$ Djelatnost samostalnih pokretnih knjižnica odnosi se na rijetko naseljena područja, odnosno područja u kojima ne postoji glavno urbano središte i gdje stacionirane službe, zbog političkih, ekonomskih ili zemljopisnih čimbenika, nisu najbolje moguće rješenje za zadovoljavanje potreba korisnika. Ta vrsta pokretne knjižnice idealna je za područja koja su zahvaćena velikim vremenskim neprilikama ili za područja koja su pretrpjela veliko ratno razaranje. ${ }^{6}$ Specijalizirane pokretne knjižnice svoje usluge prilagođavaju posebnim skupinama korisnika. Tako npr. imamo pokretne knjižnice za djecu koje svoju uslugu za djecu pružaju najčešće u školama ili za vrijeme određenih događanja. Potrebno je spomenuti i one specijalizirane pokretne knjižnice koje svoje usluge pružaju slabije pokretnim osobama, umirovljenicima u staračkim domovima, pokretne knjižnice za učenje i pisanje domaćih zadaća sa stručnim obrazovnim osobljem.

\subsection{IT oprema}

Od IT opreme, kako je propisano IFLA-inim Smjernicama, nužno je da bibliobus posjeduje računala s javnim pristupom, osobna računala samo za osoblje, uređaj za kopiranje, pisač, online-pristup referentnoj građi i uslugu prijenosa podataka. $^{7}$

Preporučljivo je da veća vozila imaju širi spektar pružanja usluga, a to se prvenstveno odnosi na dodatne aktivnosti i dodatnu opremu koja uključuje televizor, zaslon za prezentacije u Power Pointu, audio i digitalnu opremu i sl. ${ }^{8}$

\subsection{Izgradnja zbirke}

Kod planiranja izgradnje zbirke na primjeru bibliobusa koji prevozi do 2000 svezaka, preporučuje se da najzastupljenija vrsta literature bude beletristika (500 svezaka) i publicistika (400 svezaka) uz uvjet da je više građe s mekim uvezom zato što su takve knjige lakše i zauzimaju manje mjesta, što je za bibliobus bitna stavka. Zatim slijedi književnost i publicistika za djecu (oboje 200 svezaka), slikovnice (također 200 svezaka), knjige za mlade (150 svezaka), uvećani tisak i strani jezici (100 svezaka), zvučne knjige (50 svezaka) i AV građa (100 svezaka). Fond je tijekom vremena potrebno revidirati i izmjenjivati, prilagođavati se

5 Usp. Smjernice za pokretne knjižnice / prerađeno izdanje priredila radna skupina IFLA-ine Sekcije za narodne knjižnice na čelu s Ianom Stringerom; [s engleskog prevela Sanja Kovačević; stručna redakcija prijevoda Ljiljana Črnjar, Ljiljana Vugrinec]. 1. hrvatsko izd. (prema 2. prerađenom izd. Izvornika). Zagreb: Hrvatsko knjižničarsko društvo, 2011. str. 13.

6 Usp. isto, str. 14.

7 Usp. isto, str. 31.

8 Usp. isto, str. 37. 
potrebama korisnika, a iznimno je važan i dobar sustav narudžbi. ${ }^{9}$ Uspoređujući hrvatske Standarde s navedenim Smjernicama, možemo zaključiti kako postoje određene razlike pri određivanju odredbi koje se odnose na zastupljenost literature u bibliobusu. IFLA-ine Smjernice preporučuju manju zastupljenost beletristike i literature za djecu za razliku od Standarda za narodne knjižnice u Republici Hrvatskoj, tj. onog dijela koji se odnosi na bibliobuse. Točnije, prema IFLA-inim Smjernicama, $25 \%$ od ukupno 2000 svezaka opada na beletristiku, dok Standardi za narodne knjižnice u Republici Hrvatskoj preporučuju 50 \%. Pored beletristike, IFLA-ine Smjernice uvode kategoriju publicistika (20\%) i knjige za mlade $(7,5$ $\%$ ), a pored književnosti i publicistike za djecu (10\%) uvode kategoriju slikovnice (10\%). Dakle, novije IFLA-ine Smjernice detaljnije su. Također, nedostatak Standarda iz 1999. očituje se u manjku odredbi koje se odnose na pružanje usluga korisnicima s posebnim potrebama (umirovljenici, slijepe i slabovidne osobe, osobe s posebnim potrebama) te detaljniji opis informatičke opreme u IFLA-inim Smjernicama, kao i dio koji se odnosi na preporuku kako nije poželjno posjedovati AV građu u bibliobusu zbog temperaturnih razlika. Treba uzeti u obzir da su Standardi za narodne knjižnice u Republici Hrvatskoj objavljeni 1999. godine.

\section{Razvoj i trenutno stanje pokretnih knjižnica u Hrvatskoj}

Prve spoznaje o pokretnim knjižnicama u Hrvatskoj povezuju se s gradom Karlovcem i 1911. godinom kad su se knjige u obližnja sela odvozile u drvenim sanducima koji su bili smješteni u fijakerima. 60-ih godina s radom započinju prve bibliobusne službe, a prva je ustrojena 1964. godine u Karlovcu. Zatim je uslijedila Rijeka koja je svoju bibliobusnu službu uspostavila 1969. godine. 70-ih i početkom 80 -ih godina dolazi do ubrzanog razvoja bibliobusnih službi diljem zemlje. Nedugo zatim, uslijedio je pad razvoja te vrste pružanja usluga, a kao glavni razlozi pada ističu se zastarjelost vozila, nedostatak financijskih sredstava i rat koji je uslijedio početkom 90 -ih. Navedeni razlozi doveli su do ukidanja bibliobusnih službi i smanjenja broja vozila. Jedina svjetla točka tog vremena bilo je usvajanje Standarda za pokretne knjižnice - bibliobuse u Republici Hrvatskoj (1990.), te je Hrvatska bila jedna od rijetkih zemalja koja je u to vrijeme imala standarde za pokretne knjižnice. ${ }^{10}$ Početkom 21. stoljeća dolazi do poboljšanja situacije i novog uzleta bibliobusnih službi u Hrvatskoj. Godine 2001. s radom započinje Bibliobusna služba Gradske i sveučilišne knjižnice Osijek. Tijekom 2003. i 2004. godine suvremeno opremljeni bibliobusi započinju s radom u Koprivnici,

\footnotetext{
9 Usp. isto, str. 43-44.

10 Usp. Črnjar, Lj.; Lj. Vugrinec. Pokretne knjižnice u Hrvatskoj: pogled iz prošlosti u budućnost. // Pokretne knjižnice u Hrvatskoj / uredile Ljiljana Vugrinec, Ljiljana Crnjar i Frida Bišćan. Zagreb: Hrvatsko knjižničarsko društvo; Karlovac: Gradska knjižnica „Ivan Goran Kovačićc, 2012. Str. 10-15.
} 
Karlovcu, Čakovcu, Bjelovaru i Rijeci. Godine 2006. s radom započinje bibliobus Gradske knjižnice i čitaonice Vinkovci i osniva se bibliobusna služba u Gradskoj knjižnici Zadar. ${ }^{11}$

Prema dostupnim podacima, u 2013. godini u Republici Hrvatskoj djelovalo je ukupno 12 bibliobusa u 10 bibliobusnih službi i to u: Bjelovaru (Bjelovarsko-bilogorska županija), Čakovcu (Međimurska županija), Karlovcu (Karlovačka županija), Koprivnici i Križevcima (Koprivničko-križevačka županija), Osijeku (Osječko-baranjska županija), Rijeci - gradski i županijski bibliobus (Primorsko-goranska županija), Vinkovcima (Vukovarsko-srijemska županija), Zadru (Zadarska županija) i Zagrebu - 2 bibliobusa (Zagrebačka županija i Grad Zagreb). Od 2014. godine u funkciji su još dva vozila, po jedno u Zadarskoj i Karlovačkoj županiji. ${ }^{12}$ Potrebno je istaknuti da je 2015. godine došlo do gašenja bibliobusne službe Gradske i sveučilišne knjižnice Osijek, a razlozi leže u starosti vozila i učestalim kvarovima. ${ }^{13}$ Iz navedenog proizlazi da u Republici Hrvatskoj trenutno djeluje 13 bibliobusa u 9 bibliobusnih službi. Sve bibliobusne službe imaju potrebnu opremu za rad, ovisno o financijskim mogućnostima knjižnica i njihovih bibliobusnih službi. Usluge i programi svih bibliobusnih službi raznovrsni su i prilagođeni svim dobnim skupinama, s tim da prednjače radionice, igrokazi, programi za poticanje čitanja i sl. za djecu predškolske i osnovnoškolske dobi. Hrvatsko knjižničarsko društvo od 1999. godine, pa sve do danas, održava okrugle stolove o pokretnim knjižnicama u svrhu izmjenjivanja iskustava i poboljšanja rada bibliobusnih službi u Hrvatskoj te Festival bibliobusa, koji kao manifestacija predstavlja i promiče pokretne knjižnice u Hrvatskoj.

\section{Bibliobusna služba Gradske knjižnice Zadar}

Od 50-ih godina 20. stoljeća postojala je potreba za bibliobusom na području Zadarske županije, ali ona se ostvaruje tek 2006. godine zahvaljujući sredstvima dobivenim iz pretpristupnih fondova Europske unije. Gradska knjižnica Zadar natjecala se unutar programa CARDS 2002 koji se odnosio na održivi razvoj ratom zahvaćenih područja u Hrvatskoj. Povodom toga, Gradskoj knjižnici Zadar odobren je iznos od 1,752 000 kuna koji je iskorišten za nabavu i uređenje prvog bibliobusa. ${ }^{14}$ Potrebno je napomenuti da je Gradskoj knjižnici Zadar i njezinu djelatniku Mladenu Masaru dodijeljena Međunarodna nagrada IFLA-e za marketing

11 Usp. isto, str. 17-18.

12 Usp. Pezer, I.; Lj. Vugrinec. Pokretne knjižnice kao dio knjižnične mreže narodnih knjižnica u Hrvatskoj: stanje i razvojni planovi. // Vjesnik bibliotekara Hrvatske 58, 1-2(2015), str. 228.

13 Usp. Gradska i sveučilišna knjižnica Osijek: GISKO. [citirano: 2020-10-03]. Dostupno na: https://www.gskos.unios.hr/index.php/povijest-knjiznice-2/

14 Usp. Radman, N. Bibliobusna služba Gradske knjižnice Zadar. // Pokretne knjižnice u Hrvatskoj / uredile Ljiljana Vugrinec, Ljiljana Črnjar i Frida Bišćan. Zagreb: Hrvatsko knjižničarsko društvo ; Karlovac: Gradska knjižnica „Ivan Goran Kovačić“, 2012. Str. 119-120. 
u kategoriji marketinga knjižničnih usluga za promotivnu kampanju zadarskog bibliobusa pod nazivom „Knjiga u điru“. Nagrada je dodijeljena od strane IFLA-ine Sekcije za menadžment i marketing na 73. svjetskom kongresu knjižničara. Putem natječaja zaprimljene su 24 prijave iz 12 zemalja, a Gradska knjižnica Zadar osvojila je drugo mjesto. ${ }^{15}$

Drugi bibliobus s radom započinje 2014. godine i rezultat je donacije iz Njemačke, točnije, Grada Freiburga, a projekt je realiziran zahvaljujući suradnji Gradske knjižnice Zadar s Gradskom knjižnicom Freiburg te uz podršku Evangelističke župe Merzhausen, Stadtbibliotheke i Jadrolinije d.d. Učenici i profesori Prirodoslovno-grafičke škole Zadar oslikali su bibliobus. ${ }^{16}$

Fond obaju bibliobusa čine knjige, slikovnice, stripovi, dnevne novine i časopisi, enciklopedije, leksikoni, rječnici, multimedijalna građa (CD i DVD), igračke i društvene zbirke. Što se tiče tehničkih specifikacija samih bibliobusa, potrebno je naglasiti da bibliobus 1 posjeduje pristupnu rampu na električni pogon za osobe s posebnim potrebama, a godina proizvodnje je 2006., za razliku od bibliobusa 2 čija je godina proizvodnje 1986. i ne posjeduje rampu za osobe s posebnim potrebama. Osoblje bibliobusa 1 sastoji se od jednog knjižničara i jednog pomoćnog knjižničara/vozača, a osoblje bibliobusa 2 čine jedan vozač $i$ jedan knjižničar. Oba bibliobusa imaju pristup internetu i posjeduju multimedijalnu opremu (laptopi, pisači za račune, tableti za korisnike, TV i DVD-player, itd.). ${ }^{17}$

\subsection{Aktivnosti bibliobusne službe Gradske knjižnice Zadar u 2019. go- dini}

Prema Izvješću o radu Matične službe za narodne i školske knjižnice u Zadarskoj županiji za 2019. godinu bibliobusi su posjećivali ukupno 77 stajališta (81 termin) u 67 županijskih naselja. ${ }^{18}$ Broj korisnika je u godinu dana porastao s 2194 na 2385. Porast broja korisnika ima dodatnu vrijednost s obzirom na to da je došlo do pada broja stanovnika područja koja bibliobusi obilaze, s tim da treba napomenuti kako je porastu broja korisnika pridonio i besplatan upis učenika prvih razreda osnovnih škola. ${ }^{19}$

15 Usp. Masar, M. Gradska knjižnica Zadar: 1949.-2009. Zadar: Gradska knjižnica Zadar, 2009. Str. 187.

16 Usp. Gradska knjižnica Zadar. Godišnje izvješće Gradske knjižnice Zadar za 2014. godinu. Zadar: Gradska knjižnica Zadar, 2015. Str. 34-35. [citirano: 2019-08-01] Dostpno na: https:// www.gkzd.hr/sites/default/files/gi_2014_w.pdf

17 Usp. Gradska knjižnica Zadar. [citirano: 2020-08-30]. Dostupno na: http://www.gkzd.hr/bibliobus

18 Usp. Gradska knjižnica Zadar. Izvješće o radu Matične službe za 2019. g. (narodne knjižnice). Str. 10. [citirano 2020-08-10] Dostupno na: https://www.gkzd.hr/sites/default/files/IZVJESCE_ maticna_2019_NARODNE.doc

19 Isto, str. 10. 
U okviru bibliobusne službe održano je ukupno 45 događanja, od kojih su 23 tematske radionice za djecu, 5 animacijskih programa poticanja čitanja, jedna kazališna predstava za djecu, 14 grupnih posjeta na stajalištima bibliobusa te posjete gradskih škola i vrtića. Programi su održani u suradnji sa školama, vrtićima i ustanovama. Dio programa bio je priređen u sklopu manifestacija „Mjesec hrvatske knjige“ i „Zadar čita“. U realizaciji samih programa sudjelovali su djelatnici Gradske knjižnice Zadar i volonteri. Uz navedeno, treba spomenuti i da je Bibliobusna služba Gradske knjižnice Zadar sudjelovala na predstavljanjima bibliobusa u sklopu nacionalnih stručnih skupova (8. Festival hrvatskih bibliobusa, Rijeka, 7. 6. 2019. i 12. savjetovanje za narodne knjižnice u RH, Plitvice, 3. 10. 2019.). ${ }^{20} \mathrm{U}$ dokumentaciji dostupnoj u GKZD-u navedeno je da su u okviru rada bibliobusa 1 koji posjećuje kopneni dio Zadarske županije tijekom 2019. godine održana 24 događanja za djecu i dva za odrasle, dok je u okviru rada bibliobusa 2 koji obilazi priobalno i otočno područje održano 19 događanja, samo za djecu.

\section{Istraživanje o potrebama i zadovoljstvu korisnika bibliobusa Gradske knjižnice Zadar}

Cilj ovog istraživanja bio je utvrditi informacijske i čitateljske potrebe korisnika bibliobusa Gradske knjižnice Zadar, kao i njihov stupanj zadovoljstva postojećim uslugama i izborom građe.

Istraživačka pitanja bila su sljedeća:

1. Koliko se koriste građa i usluge bibliobusa?

2. Kakva je uloga sociodemografskih čimbenika u korištenju građe i usluga?

3. Koliko su korisnici zadovoljni pojedinim uslugama i izborom građe?

4. Kakva je uloga sociodemografskih čimbenika u zadovoljstvu korisnika?

5. Postoji li mogućnost poboljšanja usluga bibliobusa na temelju povratnih informacija korisnika?

Može se očekivati kako je korištenje građe i usluga bibliobusa sukladno općem korištenju u središnjoj knjižnici, ${ }^{21}$ ali uz specifične razlike vezane uz dob, spol i obrazovanje korisnika na području koje obilazi bibliobus. U skladu s ranijim istra-

\footnotetext{
20 Isto, str. 9.

${ }^{21}$ Usp. Zdravković, Ž.; V. Barada. Anketno istraživanje zadovoljstva korisnika/ca Gradske knjižnice Zadar. [citirano: 2019-10-18]. Dostupno na: http://www.gkzd.hr/pdf/dokumenti/GKZD_Anketa_Izvjestaj2009.pdf
} 
živanjima korisnika bibliobusa provedenima u Zadru 2008. godine, ${ }^{22}$ Koprivnici 2009. godine ${ }^{23}$ i Rijeci 2005. godine ${ }^{24}$ može se očekivati visok stupanj zadovoljstva korisnika, kao i konkretni prijedlozi ispitanika za unaprjeđenje usluga.

Istraživanje je provedeno koristeći dvije metode: anketu i intervju. Knjižničar bibliobusa omogućio je provedbu istraživanja na način da je dijelio upitnike korisnicima. Anketiranje korisnika provedeno je tijekom ljeta 2019., a intervjui s informatorima tijekom ljeta 2020. godine. Intervjui su provedeni kako bi se razjasnili pojedini rezultati provedenog anketiranja te kako bi se dobio detaljniji uvid u kontekst rada bibliobusa.

Anketni upitnik sadržavao je 12 pitanja na dvije stranice, kako bi ispitanici mogli u kratkom vremenu ispuniti anketu, za vrijeme korištenja usluga bibliobusa. U prvom dijelu ankete obuhvaćena su pitanja o spolu, dobi, stupnju obrazovanja, radnom statusu i mjestu korištenja bibliobusa. ${ }^{25}$ Zatim pitanje o učestalosti korištenja bibliobusa te potom tri pitanja s mogućnosti odabira više odgovora: o razlozima korištenja bibliobusa, vrsti knjiga po tematici koje najčešće posuđuju i o načinima dolaska do potrebnih informacija o građi. U tim pitanjima ponuđene su i opcije „ostalo“ za dodavanje opisnih odgovora. Nakon toga ispitanici su procijenili svoj stupanj zadovoljstva pojedinim uslugama i izborom građe, na ljestvici od 1 - potpuno nezadovoljan do 5 - potpuno zadovoljan. Uz pitanje o tome smatraju li da im je bibliobus podigao kvalitetu života ponuđeni su odgovori da/ne. $\mathrm{Na}$ kraju je postavljeno pitanje otvorenog tipa o prijedlozima unaprjeđenja usluga bibliobusa.

Upitnikom za intervjue s knjižničarima koji rade kao informatori bibliobusa obuhvaćena su pitanja otvorenog tipa koja su sadržajno pratila teme anketnih pitanja. Uz glavna pitanja koja su postavljena na neutralan način bez navođenja na određeni odgovor slijedila su potpitanja kojim se preciznije nastojalo razjasniti pojedine rezultate anketiranja.

Anketni uzorak obuhvatio je 100 ispitanika svih dobnih skupina, a potrebno je naglasiti da se istraživanje provelo za vrijeme ljeta (sredinom kolovoza), kada bibliobusi Gradske knjižnice Zadar obilaze manji broj stajališta. Podaci su prikupljeni u ukupno 20 otočnih i priobalnih mjesta, i to: Neviđane, Pašman, Ždrelac,

22 Usp. Gradska knjižnica Zadar. Godišnje izvješće 2008. Zadar: Gradska knjižnica Zadar, 2008. [citirano: 2020-10-15]. Dostupno na: https://www.gkzd.hr/pdf/dokumenti/izvjesce_2008.pdf

${ }^{23}$ Usp. Vugrinec, Lj. Istraživanje o zadovoljstvu korisnika uslugama bibliobusa. // Svezak, 12(2010), str. 16.

24 Usp. Črnjar, Lj.; J. Alić-Tadić; I. Čermelj. Primjena modela županijske bibliobusne službe na primjeru Primorsko-goranske županije. // Vjesnik bibliotekara Hrvatske 50, 3(2007), str. 61.

25 Usp. Pavlović, M. Informacijske potrebe korisnika bibliobusa Gradske knjižnice Zadar: diplomski rad. Zadar: Sveučilište, 2020. Str. 71-73. Dostupno i na: https://urn.nsk.hr/urn:nbn:hr:162:969388 [citirano 2020-11-05]. 
Kukljica, Preko, Ugljan, Lukoran, Sutomišćica, Banj, Dobropoljana, Veli Iž, Posedarje, Privlaka, Nin, Vrsi, Vir, Pakoštane, Seline, Rovanjska i Starigrad Paklenica. Najveći odaziv zabilježen je u Velom Ižu (16 ispitanika) i Preku (11 ispitanika), a najmanji, odnosno samo 1 ispitanik u Sutomišćici, Vrsima, Pakoštanima i Selinama. Manji dio uzorka, tj. 9 \% ispitanika odnosio se na tzv. „vikendaše“, koji se uslugama bibliobusa služe isključivo za vrijeme ljeta.

Planirano širenje istraživanja 2020. godine na korisnike bibliobusa 1 koji obilazi kopneni dio Zadarske županije nije provedeno zbog otežavajućih okolnosti uslijed pandemije COVID-19.

Većina ispitanika bila je ženskog spola, $69 \%$, dok su ispitanici muškog spola činili $31 \%$. Ta zastupljenost žena malo je viša u odnosu na sveukupnu zastupljenost žena od 63 \% među korisnicima knjižnica u Hrvatskoj 2019. godine. ${ }^{26}$ Prosječna dob ispitanika iznosi 38 godina. Prosječna je dob ispitanika muškog spola 41 godinu, a prosječna dob ispitanica iznosi 37 godina. S obzirom na to da su brojni korisnici bibliobusa maloljetni, zatražena je i dobivena suglasnost Etičkog povjerenstva Sveučilišta u Zadru za provođenje istraživanja i korištenje prikupljenih podataka bez traženja suglasnosti roditelja. ${ }^{27}$

S obzirom na radni status, najveći broj ispitanika čine učenici, 38 \%, među kojima je 30 učenika osnovne i 8 učenika srednje škole. Slijede ih umirovljenici, $28 \%$ te zaposleni $24 \%$. Nezaposlenih ispitanika je $7 \%$, a $2 \%$ uzorka čine studenti. U odnosu na podatke dostupne u godišnjim izvještajima Gradske knjižnice Zadar, ${ }^{28}$ može se primijetiti kako je ovim uzorkom obuhvaćen nešto veći udio odraslih korisnika. Među upisanim korisnicima bibliobusa većina su učenici, $63 \%$, dok je u ovom istraživanju uzorak obuhvatio 38 \% učenika. Slabiji odaziv učenika može se objasniti ranije navedenim podatkom da je istraživanje provedeno u ljetnim mjesecima kad nema nastave. Bibliobusi većinu stajališta imaju ispred mjesnih škola, što inače učenicima olakšava korištenje bibliobusa. Ipak, činjenica da više nemaju nastavu ne bi trebala sprječavati učenike u nastavku korištenja usluga bibliobusa. Može se zaključiti kako dio učenika tijekom školskih praznika manje redovito koristi usluge bibliobusa.

Istraživanju su u najvećoj mjeri pristupili ispitanici sa srednjom stručnom spremom - 34 \% (od kojih je svaki četvrti još uvijek učenik srednje škole ili student), slijede ispitanici kojima je stupanj obrazovanja osnovna škola - 33 \% (od kojih su

\footnotetext{
26 Usp. Knjižnice u 2019. // Državni zavod za statistiku. [citirano: 2020-10-16]. Dostupno na: https://www.dzs.hr/Hrv_Eng/publication/2020/08-03-01_01_2020.htm

27 Anketiranje je provedeno anonimno, anketni upitnik ne sadrži uznemirujuća pitanja i omogućuje učenicima izražavanje vlastitog mišljenja te uvažavanje kroz moguće unaprjeđenje usluga bibliobusa.

28 Usp. Gradska knjižnica Zadar. Izvješće o radu Matične službe za 2019. g. Nav. dj.
} 
gotovo svi još uvijek učenici, izuzev troje ispitanika), visoku stručnu spremu ima $15 \%$ ispitanika, a višu stručnu spremu $13 \%$. Magisterij ili doktorat kao stupanj obrazovanja navelo je $5 \%$ ispitanika.

\subsection{Korištenje usluga i građe}

Čak $73 \%$ ispitanika koristi usluge bibliobusa dva puta mjesečno, dakle svaki put kad bibliobus posjeti njihovo mjesto. Jednom mjesečno usluge koristi $17 \%$ ispitanika, a preostalih $10 \%$ rjeđe. Dakle, bibliobus uglavnom ima vjerne korisnike koji redovito koriste dostupne usluge.

Prema rezultatima istraživanja (slika 1), najveći broj korisnika (97 \%) kao razlog korištenja bibliobusom naveo je posudbu knjiga. Slijedi posudba multimedijalne građe (17\%), slikovnica (15\%) i stripova (11\%) te listanje novina i časopisa $(9 \%)$. Samo jedan ispitanik navodi da koristi referentnu zbirku te samo dvoje navode korištenje igračaka i društvenih igara.

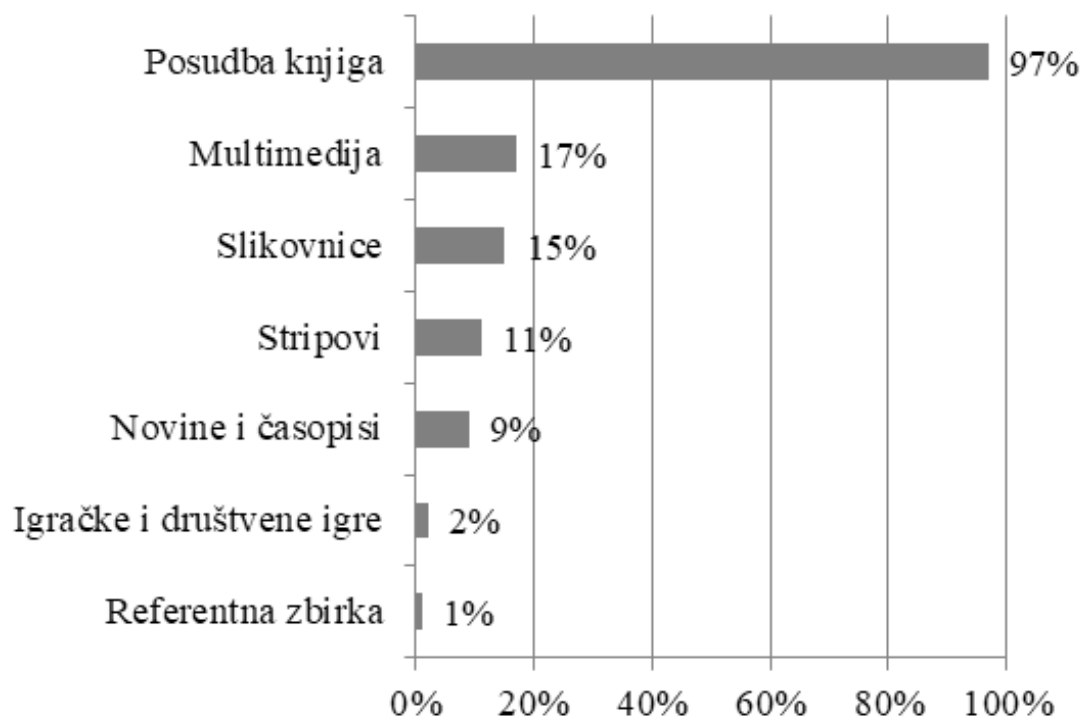

Slika 1. Razlozi korištenja usluga bibliobusa

Što se tiče posudbe građe s obzirom na tematiku, na slici 2 vidljivo je kako najveći broj ispitanika, njih $49 \%$ posuđuje beletristiku, dok $37 \%$ ispitanika posuđuje literaturu za djecu. Ispitanici najmanji interes pokazuju za knjige vezane uz sport (6\% ispitanika) i stručnu literaturu (5\% ispitanika). 


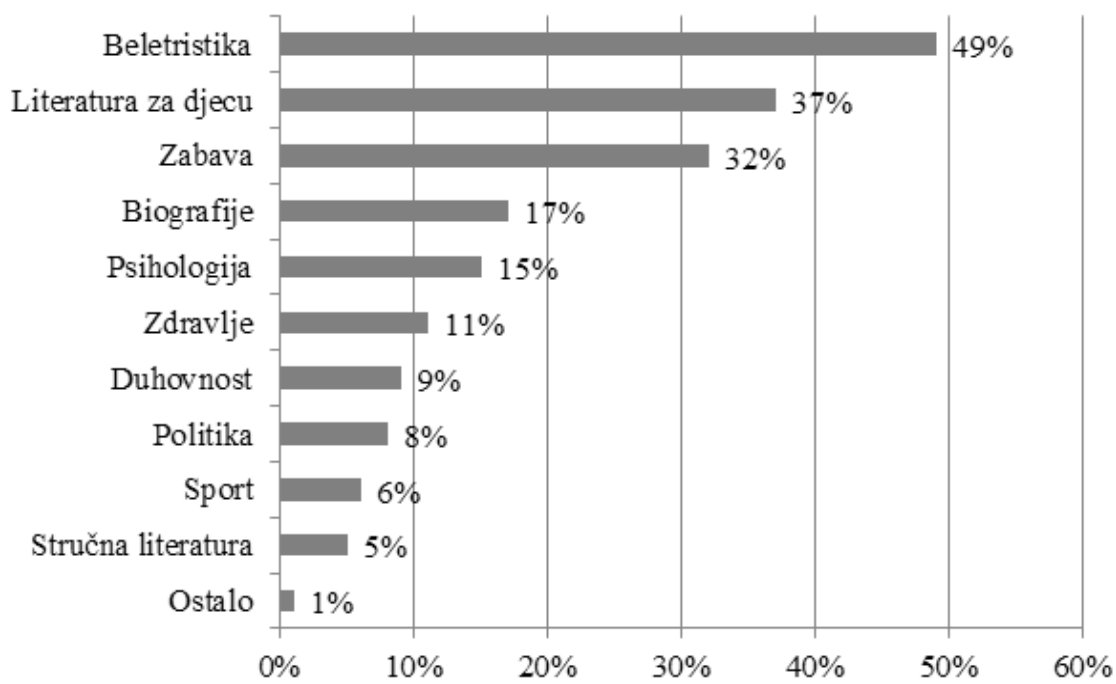

Slika 2. Posudba knjiga po tematici

Pružanje informacija o građi jedna je od ključnih usluga koje pružaju djelatnici bibliobusa. Rezultati anketiranja pokazuju da ispitanici do informacija dolaze na razne načine. Potpuno samostalno do informacija o građi dolazi 34 \% ispitanika, a isključivo putem upita knjižničaru do informacija dolazi $8 \%$ ispitanika. Sveukupno $80 \%$ ispitanika samostalno dolazi do informacija o građi, $50 \%$ ispitanika preko upita knjižničaru, dok ih je 34 \% izabralo i preporuku prijatelja kao odgovor. U tablici 1 navedene su sve kombinacije prikupljenih odgovora.

Tablica 1. Načini dolaska do informacija o građi i uslugama

\begin{tabular}{|l|c|}
\hline Dolazak do informacija & $\%$ odgovora \\
\hline Samostalno & $34 \%$ \\
\hline Samostalno, Upit knjižničaru & $21 \%$ \\
\hline Samostalno, Preporuka prijatelja, Upit knjižničaru & $18 \%$ \\
\hline Upit knjižničaru & $8 \%$ \\
\hline Samostalno, Preporuka prijatelja & $7 \%$ \\
\hline Preporuka prijatelja, Upit knjižničaru & $5 \%$ \\
\hline Preporuka prijatelja & $3 \%$ \\
\hline Ostalo: Internet & $2 \%$ \\
\hline Samostalno, Preporuka prijatelja, Ostalo: Internet & $1 \%$ \\
\hline Nije odgovoreno & $1 \%$ \\
\hline
\end{tabular}


Informator (I1) je tijekom intervjua procijenio kako približno $20 \%$ korisnika samostalno bira građu, dok ostalih $80 \%$ korisnika, prema iskustvu informatora, traže savjet i preporuku. S obzirom na to da $50 \%$ ispitanika navodi kako do informacija dolazi putem upita knjižničaru, što je niže od procijenjenih $80 \%$, moguće je da postoje razlike u percepciji knjižničara i korisnika o tome što se sve smatra upitom i koliko su upiti zastupljeni. Na pitanje o tome na što bi se moglo odnositi samostalno dolaženje do informacija, informator (I1) navodi portale nakladnika koje korisnici prate i kad se pojavi novi naslov traže taj novi naslov. Drugi informator (I2) dodatno primjećuje kako čitatelji prate grupe za ljubitelje knjiga na društvenim mrežama, kao i priloge televizijskih emisija poput „Vijesti iz kulture“ ili „Dobro jutro Hrvatska“:

„Ponekad korisnici znaju doći s upitom imamo li u bibliobusu baš onu knjigu koju su vidjeli u prilogu neke od navedenih emisija.“

Na temelju komentara knjižničara informatora može se zaključiti kako korisnici koji samostalno dolaze do informacija uglavnom prate portale, društvene mreže i televizijske emisije u kojima se predstavljaju nova knjižna izdanja.

\subsection{Uloga sociodemografskih čimbenika u korištenju građe}

Analizirane su razlike s obzirom na spol, kao i razlike između dviju grupa koje su identificirane kao ključne skupine korisnika bibliobusa: učenike i odrasle osobe.

$\mathrm{Ne}$ postoji razlika u učestalosti korištenja bibliobusa $\mathrm{s}$ obzirom na spol (Mann-Whitneyev $\mathrm{U}$ test $=679, \mathrm{Z}=0,73, \mathrm{p}=0,47$ ). Za sve medijan učestalosti iznosi 5 , što znači da gotovo svi muškarci i žene koriste bibliobus svaki put kad posjećuje stajalište. Među ostalim rezultatima, prisutne su određene razlike s obzirom na spol, ali radi se o građi koja se malo koristi. Primjerice, 6 od 23 ispitanika i 3 od 62 ispitanice čitaju novine i časopise. Takva razlika nije slučajnost (Yates $\chi^{2}=4,27 \mathrm{df}=1 \mathrm{p}=0,04$ ), ali radi se o vrlo malom broju korisnika. Informator (I1) objašnjava kako se ne radi o čitanju, već o listanju novina jer je vrijeme stajanja bibliobusa ograničeno. Također, u uzorku od 100 korisnika bibliobusa, pet muškaraca i dvije žene posuđuju knjige političke tematike (Yates $\chi^{2}=3,99 \mathrm{df}=$ $1 \mathrm{p}=0,045)$. I u tom slučaju radi se o vrlo malom broju korisnika. Informatori u intervjuima ističu kako dobro poznaju gotovo sve redovite korisnike bibliobusa i njihove čitateljske navike, te za sve pronalaze literaturu koja bi im mogla biti zanimljiva.

Postoje razlike u posudbi knjiga različite tematike između dviju glavnih skupina korisnika: učenika i odraslih osoba. Beletristiku posuđuje 48 odraslih osoba (72\% od 62 odrasle osobe) i samo jedan učenik (2,6\%), dok multimediju posuđuje 12 učenika $(32 \%$ od 38$)$ i $5(8 \%$ od 62$)$ odraslih osoba $\left(\chi^{2}=10,6 \mathrm{df}=1 \mathrm{p}<0,01\right)$. Ta- 
kođer, zabavne knjige više posuđuju učenici $\left(\chi^{2}=21,9 \mathrm{df}=1 \mathrm{p}<0,01\right)$, tj. 22 učenika ( $61 \%$ od 36$)$ i 10 odraslih ( $16 \%$ od 64$)$. Literaturu za djecu posuđuju i djeca i odrasli $\left(\chi^{2}=1,3 \mathrm{df}=1 \mathrm{p}=0,25\right)$, tj. 21 odrasla osoba (33\%) i 16 učenika $(44 \%)$. Slikovnice većinom posuđuju odrasli, za svoju mlađu djecu. Stripove podjednako posuđuju djeca i odrasli $\left(\chi^{2}=0,48 \mathrm{df}=1 \mathrm{p}=0,49\right)$, tj. posuđuje ih pet učenika i šest odraslih osoba srednje dobi. Informator I2 komentira kako u bibliobus „dolaze i stariji korisnici te uzimaju stripove, multimediju i slikovnice za djecu i unuke“". Zbog ograničenog opsega ankete nije detaljnije ispitano koliko se građe posuđuje za vlastite potrebe, a koliko za članove obitelji.

Knjige o zdravlju, psihologiji, politici, duhovnosti, te stručne knjige i biografije se rjeđe posuđuju, mada sveukupno takvu građu koja se većinom kategorizira kao publicistika posuđuje velik broj odraslih osoba ( $92 \%$ odraslih i $24 \%$ učenika). Na kraju, zanimljiv je podatak da su svih 6 osoba koje posuđuju knjige sportske tematike učenici. Ukratko, među anketiranim korisnicima bibliobusa, učenici više posuđuju multimediju, zabavne i knjige o sportu, dok odrasli više posuđuju beletristiku i popularnu publicistiku te slikovnice za svoju mlađu djecu. Knjige za djecu posuđuju sami učenici, ali i dio odraslih korisnika za svoju djecu i unuke.

\subsection{Zadovoljstvo uslugama bibliobusa}

Utvrđene su razlike u zadovoljstvu korisnika pojedinim uslugama bibliobusa, ANOVA $F(8,384)=11,81, \mathrm{p}<0,01$.

Tablica 2. Stupanj zadovoljstva uslugama bibliobusa

\begin{tabular}{|l|l|l|l|l|l|}
\hline & \multicolumn{1}{|c|}{$\mathbf{N}$} & $\mathbf{M}$ & Minimum & Maksimum & SD \\
\hline Usluga djelatnika & 88 & $\mathbf{4 , 9 8}$ & 4 & 5 & 0,15 \\
\hline Mjesto stajanja bibliobusa & 85 & 4,75 & 3 & 5 & 0,55 \\
\hline Izbor slikovnica & 59 & 4,68 & 3 & 5 & 0,65 \\
\hline Izbor dječje literature & 61 & 4,67 & 3 & 5 & 0,63 \\
\hline Učestalost dolaska bibliobusa & 84 & 4,67 & 2 & 5 & 0,68 \\
\hline Izbor knjiga & 94 & 4,57 & 3 & 5 & 0,68 \\
\hline Izbor stripova & 57 & $\mathbf{4 , 4 9}$ & 3 & 5 & 0,71 \\
\hline Izbor multimedije & 57 & $\mathbf{4 , 4 9}$ & 3 & 5 & 0,76 \\
\hline Radionice & 50 & $\mathbf{4 , 0 0}$ & 1 & 5 & 1,16 \\
\hline
\end{tabular}


Iz navedenih rezultata vidljivo je da su korisnici najviše zadovoljni uslugama djelatnika ( $M=4,98$, vidi tablicu 2). Stupanj zadovoljstva uslugama djelatnika statistički je značajno viši nego stupanj zadovoljstva izborom stripova i multimedije (post hoc HSD test). Stupanj zadovoljstva radionicama značajno je niži u odnosu na sve ostale usluge. Pritom su radionicama u prosjeku umjereno zadovoljni ( $M=4,00$, vidi tablicu 2). Ovdje je potrebno istaknuti kako je tek svaki drugi ispitanik procijenio svoje zadovoljstvo radionicama. Radionice su bile povremeno organizirane, uglavnom za učenike osnovnih škola, pa ih svi nisu niti mogli pohađati. Na temelju dokumentacije dostupne u GKZD-u, u okviru rada bibliobusne službe 2 tijekom 2019. godine održano je 19 događanja za djecu koje je posjetilo 461 djece. To je približno $62 \%$ djece koja su korisnici bibliobusa 2 . Također, nisu održana događanja za odrasle. S obzirom na to da je svoje zadovoljstvo radionicama procijenilo 19 odraslih osoba i 30 učenika ( $79 \%$ anketiranih učenika), može se zaključiti kako znatan dio tih ispitanika uopće nije prisustvovao niti radionicama niti drugim događanjima. Također, na ranijem pitanju među razlozima korištenja bibliobusom nitko nije izabrao radionice koje su bile među ponuđenim odgovorima. Dakle, anketirani ispitanici svoju procjenu iznijeli su na temelju općeg dojma ili na temelju sjećanja s radionica i ostalih događanja održanih tijekom ranijih godina. U svakom slučaju, stupanj zadovoljstva radionicama ne može se tumačiti kao pouzdan pokazatelj stvarnog zadovoljstva korisnika tom uslugom.

Informator (I2) u intervjuu opisuje radionice na sljedeći način:

„Programi i radionice su usmjereni k privlačenju mlađih korisnika, postojećih i potencijalnih novih te stvaranju čitalačkih navika u ranoj dobi. Odaziv je uvijek velik, dolaze čitavi razredi ili čak čitave škole - ovisno o veličini škole, na mnogim bibliobusnim stajalištima nalaze se male područne škole. Mlađim korisnicima takvi programi i radionice budu zabavni i rado sudjeluju u njima, a djelatnici škola i vrtića ističu korisnost održanih programa i radionica te potiču daljnju suradnju s Knjižnicom putem bibliobusa.“

Dakle, dojam informatora je kako su radionice korisnicima zabavne, pogotovo mlađim korisnicima. Dok informatori obavljaju zaduženja i razduženja u bibliobusu, radionice za djecu uglavnom vode njihove kolegice s dječjeg odjela GKZD-a, a neke su realizirali i volonteri, pojašnjavaju informatori (I1 i I2).

Od ostalih podataka u tablici 2, može se primijetiti visoko zadovoljstvo mjestom stajanja i učestalosti dolazaka bibliobusa. Također, na dodatnom pitanju, izuzev dvoje ispitanika svi su se složili s tvrdnjom da im bibliobus podiže kvalitetu života. Može se zaključiti kako su korisnici zadovoljni svim uslugama, ali ipak su najviše zadovoljni uslugama samih djelatnika. Također, dio korisnika nije potpuno zadovoljan izborom stripova i multimedije. 


\subsection{Uloga sociodemografskih čimbenika u zadovoljstvu korisnika}

Na temelju Spearmanovih rang korelacija u tablici 3 može se zaključiti da su mlađi korisnici zadovoljniji izborom građe, pogotovo izborom slikovnica $(\mathrm{R}=$ 0,41) i knjiga $(\mathrm{R}=-0,38)$, za razliku od starijih korisnika.

Slikovnice većinom posuđuju roditelji za djecu predškolske dobi, pa su možda zbog toga anketirani učenici osnovnih i srednjih škola manje kritični vezano uz izbor slikovnica. Nadalje, o mogućim razlozima zašto su ponekad stariji korisnici manje zadovoljni izborom građe pojašnjava informator I2:

„Što su korisnici stariji i obrazovaniji, njihovi upiti mogu biti kompleksniji te njihove želje i potrebe mogu premašiti ono što fond bibliobusa nudi.“

Moguće je da su potrebe starijih korisnika veće. Na prvi pogled, u skladu s navedenim citatom je i negativna korelacija obrazovanja i zadovoljstva izborom knjiga $(\mathrm{R}=-0,29)$. Međutim, korelacija obrazovanja i zadovoljstva izborom knjiga nije značajna na poduzorku odraslih korisnika. Dakle, radi se o tome da su učenici najzadovoljniji, a oni još ne mogu imati viši stupanj obrazovanja.

Tablica 3. Rang korelacije dobi, obrazovanja, učestalosti korištenja i zadovoljstva uslugama bibliobusa

\begin{tabular}{|l|c|c|c|}
\hline & Dob & Obrazovanje & Učestalost korištenja \\
\hline Učestalost korištenja & 0,04 & $-0,01$ & 1 \\
\hline Izbor knjiga & $\mathbf{- 0 , 3 8}$ & $\mathbf{- 0 , 2 9}$ & 0,06 \\
\hline Izbor stripova & $\mathbf{- 0 , 3 4}$ & $-0,13$ & $-0,05$ \\
\hline Izbor slikovnica & $\mathbf{- 0 , 4 1}$ & $-0,24$ & 0,07 \\
\hline Izbor dječje literature & $\mathbf{- 0 , 2 8}$ & $-0,17$ & 0,24 \\
\hline Izbor multimedije & $\mathbf{- 0 , 3 0}$ & $-0,25$ & $\mathbf{0 , 3 5}$ \\
\hline Radionice & $-0,02$ & $-0,01$ & 0,26 \\
\hline Učestalost dolaska bibliobusa & $-0,01$ & 0,01 & 0,17 \\
\hline Mjesto stajanja bibliobusa & 0,12 & 0,16 & $-0,10$ \\
\hline
\end{tabular}

Korisnici koji češće koriste usluge bibliobusa zadovoljniji su izborom multimedije $(\mathrm{R}=0,35)$. $\mathrm{S}$ obzirom na to da bibliobus najčešće ima stajališta ispred škola, učenici češće imaju priliku koristiti usluge. U skladu s tim, mlađi korisnici zadovoljniji su izborom multimedije $(\mathrm{R}=-0,30)$. Ranije je već navedeno da multimediju posuđuje 12 učenika i 5 odraslih osoba. Razlika između tih dviju grupa 
korisnika značajna je na Welchovom $t$-testu $(t=2,1, d f=33,8, p=0,04)$. Učenici su u prosjeku jako zadovoljni izborom multimedije, $\mathrm{M}=4$,7, dok su odrasli uglavnom zadovoljni, $M=4,2$. Kroz intervjue su dobivena pojašnjenja kako se multimedija iz središnje knjižnice ne može posuđivati u bibliobusu jer je rok posudbe u središnjoj knjižnici dva dana, dok bibliobus obilazi stajališta jednom u 14 dana. Dakle, izbor multimedije u bibliobusu nešto je slabiji. Bez obzira na to, kako je već prikazano u tablici 2, stupanj zadovoljstva izborom multimedije u prosjeku je uglavnom visok, ali ipak malo niži od zadovoljstva uslugama djelatnika.

U tablici 4 navedeno je da su učenici najzadovoljniji izborom knjiga, dok se zaposleni ispitanici i umirovljenici ne razlikuju značajno po pitanju zadovoljstva izborom knjiga ( $=0,56$; vidi tablicu 4). Dakle, odrasli korisnici uglavnom su zadovoljni izborom knjiga, ali ipak ne u potpunosti kao učenici. Ranije navedena rang korelacija dobi i zadovoljstva izborom knjiga odnosi se upravo na ti razliku između učenika i odraslih korisnika.

$\mathrm{Na}$ temelju rezultata u tablici 3 može se zaključiti kako s obzirom na dob i obrazovanje nema razlika u učestalosti korištenja bibliobusa niti u zadovoljstvu radionicama.

Tablica 4. Zadovoljstvo izborom knjiga s obzirom na radni status

\begin{tabular}{|l|c|c|c|c|c|c|}
\hline Radni status & $\begin{array}{c}\text { Izbor knjiga } \\
\mathbf{M}\end{array}$ & $\begin{array}{c}\text { Izbor knjiga } \\
\mathbf{N}\end{array}$ & $\begin{array}{c}\text { Izbor knjiga } \\
\text { SD }\end{array}$ & $\mathbf{\{ 1 \}}$ & $\{\mathbf{2}\}$ & $\{\mathbf{3}\}$ \\
\hline Učenik $\{\mathbf{1}\}$ & $\mathbf{4 , 9 2}$ & 37 & 0,28 & & $\mathbf{0 , 0 3 *}$ & $\mathbf{0 , 0 0 *}$ \\
\hline Zaposlen $\{\mathbf{2}\}$ & $\mathbf{4 , 4 5}$ & 22 & 0,60 & $\mathbf{0 , 0 3}$ & & 0,56 \\
\hline Umirovljenik $\{\mathbf{3}\}$ & $\mathbf{4 , 2 7}$ & 26 & 0,87 & $\mathbf{0 , 0 0 *}$ & 0,56 & \\
\hline
\end{tabular}

$* \mathrm{p}<0,05$ (HSD test); ANOVA F $(2,82)=9,89, \mathrm{p}=0,0001 ; \mathrm{M}-$ aritmetička sredina; $\mathrm{N}-$ broj ispitanika; SD - standardna devijacija

Na temelju visokog zadovoljstva učenika može se zaključiti kako se njima posvećuje najviše pozornosti kroz građu i usluge. Prema izvještajima Gradske knjižnice Zadar, najveći broj korisnika bibliobusa čine učenici, pa je očekivano da se izbor knjiga više prilagođava njihovim potrebama, koliko god se nastoje ispuniti potrebe svih korisnika podjednako. Na taj način može se tumačiti niz negativnih korelacija dobi i zadovoljstva izborom građe. Nadalje, informator I1 u intervjuu objašnjava kako bibliobus najviše dolazi pred škole i u jutarnjim satima, u vrijeme kad mnogi odrasli rade, pa ne mogu koristiti bibliobus. Međutim, dodaje i sljedeće:

„Izlazimo u susret, npr. jedna gospođa javi što joj treba i na povratku joj stanemo, nakon što joj završi posao.“ 
U skladu s tim, kao što je već navedeno, korisnici su izrazito zadovoljni uslugama djelatnika.

Ispitanici koji pitaju knjižničara za informacije i savjete manje su zadovoljni izborom stripova $(M=4,29)$, za razliku od ispitanika koji ne pitaju knjižničare za informacije $(M=4,69), t(55)=2,22, p=0,03$. Iz toga se može zaključiti kako bi pojedini korisnici željeli veći izbor stripova, nisu potpuno zadovoljni izborom i zbog toga se obraćaju knjižničarima za informacije. Informator I1 objašnjava situaciju s izborom građe koja se rjeđe koristi na sljedeći način:

„Postoje upiti što se tiče stripova, ali smatramo da nije potrebno nagomilavati veliku količinu građe za bibliobus, jednostavnije mi je poslužiti se odjelom za odrasle. Za 14 dana donesem knjigu ili strip. Nemamo mjesta za sve, primjerice za znanstveno popularnu literaturu. Više se usmjeravamo na beletristiku.“

Dakle, iz praktičnih razloga građa koja se rjeđe posuđuje dostupna je tek na upit. Ranije je navedeno kako je zadovoljstvo izborom stripova i multimedije malo niže nego zadovoljstvo uslugama djelatnika, mada se zapravo radi o relativno visokim razinama zadovoljstva izborom stripova i multimedije $(M=4,49$, vidi tablicu 2).

Tablica 5. Razlika u posudbi beletristike s obzirom na načine dolaska do informacija (Upit knjižničaru)

\begin{tabular}{|l|c|c|c|}
\hline Korisnici & Ne pitaju knjižničara & Pitaju knjižničara & $\Sigma$ \\
\hline Ne posuđuju beletristiku & $\underline{30}$ & 18 & 48 \\
\hline Posuđuju beletristiku & 18 & $\underline{31}$ & 49 \\
\hline$\Sigma$ & 48 & 49 & 97 \\
\hline
\end{tabular}

Pearson $\chi^{2}=6,4 \mathrm{df}=1 \quad \mathrm{p}=0,011$

Analizom razlika u posudbi pojedinih vrsta građe s obzirom na to pitaju li knjižničare za savjet, utvrđeno je kako korisnici koji pitaju za savjet češće posuđuju beletristiku (vidi tablicu 5). Isto vrijedi za posudbu biografija i stripova, mada se ta građa rjeđe posuđuje. Dakle, među korisnicima koji su aktivni u posudbi ujedno je više onih koji aktivno traže savjete pri izboru građe, za razliku od onih koji rjeđe posuđuju i rjeđe pitaju za informacije i savjete.

\subsection{Mogućnosti poboljšanja usluga}

Najveći broj ispitanika izrazio je želju za širim izborom knjiga ili više novijih izdanja (13 ispitanika, vidi tablicu 6), zatim bolji raspored knjiga na policama (3 
ispitanika) i duži ostanak bibliobusa (2 ispitanika). Po jedan ispitanik predlaže bolju informiranost, ukidanje naplate rezervacije, učestaliji dolazak bibliobusa i rad klima uređaja.

Tablica 6. Prijedlozi i sugestije korisnika

\begin{tabular}{|l|c|}
\hline Komentar & Broj odgovora \\
\hline Širi izbor knjiga & 7 \\
\hline Više novijih izdanja & 4 \\
\hline Nezadovoljstvo rasporedom knjiga & 3 \\
\hline Duži ostanak bibliobusa & 2 \\
\hline Bolja informiranost & 1 \\
\hline Ukidanje naplate rezervacije & 1 \\
\hline Učestaliji dolazak bibliobusa & 1 \\
\hline Rad klima uređaja & 1 \\
\hline
\end{tabular}

Mogu se izdvojiti neki od prijedloga korisnika: „Da bibliobus dolazi češće i da više ostaje“; „Želio bih da u izboru knjiga bude više najnovije literature iz strane književnosti i stručne literature.“; „Ako je moguće više naslova i novih autora, svjetskih i domaćih“.

Relativno malo ispitanika dalo je svoje prijedloge i sugestije, $15 \%$. Možda većina ispitanika nakon detaljnih anketnih pitanja više nije imala potrebu upisivati odgovore na završno pitanje otvorenog tipa. Također, ranije prikazani rezultati pokazuju visok stupanj zadovoljstva većinom postojećih usluga, pa i to može biti razlog zašto većina ispitanika nije imala dodatnih komentara. Prijedlozi za proširenjem izbora knjiga odnose se na odrasle korisnike koji za razliku od učenika nisu u potpunosti zadovoljni.

Odgovori informatora detaljniji su. Ističu kako se zbog praktičnih razloga ne može uvijek imati dostupan velik broj najnovijih izdanja, što je problem koji nije svojstven samo za bibliobus, nego i za središnju knjižnicu. Kao i jedan korisnik, informatori posebno ističu potrebu za klima uređajem i boljim internet pristupom, prije svega radi korisnika koji bi koristili WiFi, ali i za obavljanje posudbe i razduženja građe. Nadalje, knjižničari informatori spominju kako djeca traže igrice, ali im umjesto igrica nude priručnike za trenutno popularne računalne igre, što djeca rado prihvaćaju. 


\section{Rasprava}

Predstavljene rezultate potrebno je usporediti s ranije objavljenim, barem djelomično usporedivim istraživanjima. Dostupni su podaci o zadovoljstvu korisnika bibliobusa Gradske knjižnice Zadar iz 2008. godine. ${ }^{29} \mathrm{U}$ tom istraživanju bilo je anketirano 114 korisnika, s kraćim anketnim upitnikom. Rezultati su pokazali kako je $88 \%$ korisnika redovito koristilo usluge bibliobusa, dok je 2019. godine $73 \%$ ispitanika usluge koristilo redovito - prilikom svake posjete bibliobusa. Dodatnih $17 \%$ ispitanika koristilo je bibliobus prilikom svakog drugog stajanja u njihovom mjestu. Dakle, malo se smanjila učestalost korištenja. Uspoređujući dobivene rezultate s onima u Koprivnici, ${ }^{30}$ gdje je provedeno istraživanje na 162 korisnika bibliobusa 2009. godine, nailazimo na slične podatke, uz neznatno veći postotak neredovitih korisnika. U tom istraživanju $70 \%$ ispitanika navelo je da koristi usluge bibliobusa redovito, a $25 \%$ da usluge bibliobusa koristi povremeno. Iz svega navedenog možemo zaključiti kako bibliobusi većinom imaju redovite i vjerne korisnike.

U istraživanju iz 2008. godine $80 \%$ ispitanika smatralo je da im je bibliobus Gradske knjižnice Zadar podigao kvalitetu života te $75 \%$ da bi prestanak dolazaka bio štetan za njihovo mjesto. Nakon 11 godina gotovo svi anketirani ispitanici, tj. 98 \% složilo se s tvrdnjom kako im bibliobus podiže kvalitetu života. Dodatna usporedba moguća je s korisnicima bibliobusa iz Rijeke 2005. godine ${ }^{31}$ i Koprivnice 2009. godine. U Rijeci, $81 \%$ ih je smatralo da im bibliobus podiže kvalitetu života, a u Koprivnici $89 \%$, i to u razonodi, obrazovanju i kulturi.

Posljednji podatak koji se može usporediti s 2008. godinom je udio korisnika koji su zadovoljni građom. Među anketiranim korisnicima zadarskog bibliobusa iz 2008. godine $76 \%$ ih je bilo zadovoljno ponuđenom građom. U ovom istraživanju provedenom 2019. godine postoci ispitanika koji su uglavnom ili potpuno zadovoljni (odgovori 4 i 5) u rasponu su od $84 \%$ za izbor multimedije do $89 \%$ za izbor knjiga. Dakle, može se zaključiti kako je porastao stupanj zadovoljstva korisnika, mada se smanjio broj najaktivnijih korisnika. Za dodatnu usporedbu, u Koprivni$\mathrm{Ci}^{32}$ je 2009. godine bio još veći postotak korisnika koji su zadovoljni građom i to $68 \%$ potpuno zadovoljnih i $29 \%$ djelomično zadovoljnih. U Koprivnici je $93 \%$ korisnika bilo zadovoljno uslugom djelatnika, što je vrlo slično gotovo potpunom zadovoljstvu uslugama djelatnika zadarskog bibliobusa.

Dostupni su i podaci istraživanja iz 2009. o zadovoljstvu korisnika Gradske knjižnice Zadar. ${ }^{33}$ Naravno, rezultati nisu izravno usporedivi s obzirom na ograni-

\footnotetext{
29 Usp. Gradska knjižnica Zadar. Godišnje izvješće 2008. Nav. dj.

30 Usp. Vugrinec, Lj. Nav. dj., str. 16.

31 Usp. Črnjar, Lj.; J. Alić-Tadić; I. Čermelj. Nav. dj., str. 61.

32 Usp. Vugrinec, Lj. Nav. dj., str. 16.

33 Usp. Zdravković, Ž.; V. Barada. Nav. dj.
} 
čenja vezana uz specifičnosti uzoraka ispitanika te prostornih uvjeta i dostupnosti građe. Bibliobus je namijenjen mještanima i djeci koja žive, rade i školuju se u malim mjestima Zadarske županije i kojima su knjižnice u gradu nedostupne. Usporedbe istovrsnih korisničkih skupina pokazuju kako su navike i potrebe korisnika bibliobusa i središnje knjižnice slične. Odrasli korisnici više posuđuju beletristiku i publicistiku te više čitaju novine, dok učenici više posuđuju multimediju. Također, mlađi korisnici zadovoljniji su izborom multimedije negoli odrasli, u obama istraživanjima. Primjetna je razlika u korištenju takve građe zbog znatno većeg fonda u središnjoj knjižnici. Prema IFLA-inim Smjernicama AV građa treba činiti $10 \%$ zbirke bibliobusa, uz $5 \%$ zvučnih knjiga. Preostali postotak čine knjige. Znatno veći postotak mladih posuđivao je CD/DVD građu u središnjoj knjižnici (82\%) nego u bibliobusu (32\%). Knjižničari informatori objasnili su kako se za potrebe bibliobusa ne može koristiti multimedijalna građa iz središnje knjižnice zbog kratkog roka posudbe. To korisnicima bibliobusa ograničava širinu izbora. Uzimajući to u obzir, moglo se očekivati i niže zadovoljstvo korisnika fondom multimedijske građe. Ipak, među korisnicima multimedije, učenici su jako zadovoljni izborom, dok su odrasli korisnici uglavnom zadovoljni. Također, vrijeme stajanja bibliobusa vremenski je ograničeno. Bibliobus se najčešće zadrži na stajalištu oko 50 minuta, uz raspon od 40 minuta do najdulje sat i pol. Stoga je razumljivo slabije korištenje novina i časopisa. Također, središnja knjižnica ima čitaonicu, dok je prostor bibliobusa znatno manji. Standardi za narodne knjižnice u Republici Hrvatskoj preporučuju da se „manji dio postotka odnosi na časopise i priručnu literaturu“. Na temelju toga, za očekivati je bilo kako će korisnici u najvećem broju posuđivati knjige, a znatno manje koristiti usluge bibliobusa po pitanju posudbe multimedijalne građe i čitanja novina i časopisa.

Dobiveni rezultati o načinima dolaska do informacija mogu se usporediti $\mathrm{s}$ podacima iz projekta Istraživanja informacijskim potreba i čitateljskih navika građana Hrvatske. ${ }^{34}$ U anketiranju provedenom 2010. godine, učenici 7. i 8. razreda osnovnih škola su na pitanje o tome što utječe na njihov izbor knjige u najvećem broju izabrali zanimljiv naslov, $47 \%$, zatim temu knjige $43 \%$ i preporuke prijatelja $27 \%$, dok samo $9 \%$ učenika navodi preporuke učitelja ili knjižničara. U okviru istog projekta provedeno je i istraživanje s odraslim korisnicima. Na pitanje o tome što utječe na njihov izbor knjiga za čitanje, 41 \% odraslih korisnika knjižnica ipak navodi kako traže informacije od knjižničara za preporuku što čitati u slobodno vrijeme..$^{35}$ Također, nešto više su se oslanjali na savjete prijatelja, 58 \%, zatim novine, radio i televiziju $49 \%$ te internet $46 \%$. Na nizak postotak učenika

34 Usp. Stričević, Ivanka; Srećko Jelušić. Informacijske potrebe i čitateljski interesi građana Hrvatske. // Međunarodni interdisciplinarni stručni skup Knjiga i slobodno vrijeme: zbornik radova / uredile Elli Pecotić, Snježana Buczkowska i Katarina Krolo Žužul. Split: Gradska knjižnica Marka Marulića, 2011. Str. 24-25.

35 Usp. Juric, M. Istraživanja čitateljskih navika i informacijskih potreba građana Hrvatske: kratki pregled rezultata. // Hrčak 46-47(2012), str. 5. 
koji se oslanjaju na savjete učitelja i knjižničara mogao je utjecati oblik postavljenog pitanja, kao i to što su u istoj kategoriji bili učitelji i knjižničari. U ovom istraživanju s korisnicima bibliobusa, u kojem su više obuhvaćeni odrasli korisnici (62\%), veći je postotak ispitanika koji su, između ostalog, naveli kako pitaju knjižničara za savjet, približno $50 \%$ korisnika. Dodatno, jedan informator na temelju osobnog iskustva procjenjuje kako još više, oko $80 \%$ korisnika traži savjet oko izbora građe. Većina anketiranih ispitanika navodi kako samostalno dolazi do informacija, zatim upitom knjižničaru i preporukom prijatelja. Knjižničari kroz intervjue tumače kako se samostalno informiranje vjerojatno odnosi na praćenje izlaska novih izdanja na mrežnim stranicama nakladnika, na društvenim mrežama i televizijskim emisijama. Kako bi se preciznije utvrdile razlike u percepcijama korisnika i knjižničara o tome koliko se koriste preporuke knjižničara, potrebna su dodatna istraživanja. Također, način postavljanja anketnog pitanja znatno utječe na odgovore ispitanika, pa su potrebne i druge metode za istražiti na koje sve načine korisnici dolaze do informacija.

Među ponuđenim odgovorima niti jedan ispitanik nije naveo radionice kao razlog korištenja bibliobusom, iako je kasnije svaki drugi vrednovao zadovoljstvo tom uslugom. Možda se radi o tome da učenici ne dolaze u bibliobus s ciljem sudjelovanja u radionici ili te radionice ne doživljavaju kao dio usluga bibliobusa. Razne radionice za djecu, primjerice radionice uvodnog programiranja pod nazivom MICRO:BITno održavaju se u školama koje posjećuje bibliobus i provode ih volonteri i drugi djelatnici knjižnice, dok za to vrijeme informatori rade redovne poslove u bibliobusu. Također, specifičnost tih radionica je da na njima može sudjelovati mali broj polaznika. Ranije je objašnjeno kako dio korisnika nije niti mogao biti na radionicama zbog ograničenog broja sudionika. Svoje zadovoljstvo radionicama ocijenili su i odrasli korisnici za koje nije održana niti jedna radionica, pa se podaci o zadovoljstvu ne mogu tumačiti kao pouzdani i valjani.

Razlike s obzirom na dob i zadovoljstvo uslugama bibliobusa očituju se po rezultatima koji pokazuju da su mlađi korisnici zadovoljniji izborom građe. Sukladno tome, po pitanju izbora knjiga, najveće zadovoljstvo iskazuju učenici, slijede ih zaposleni ispitanici i umirovljenici koji se međusobno ne razlikuju značajno po pitanju zadovoljstva izborom knjiga. $\mathrm{U}$ fondu kojim je bibliobus 2 raspolagao 2019. godine nalazi se 8356 jedinica građe, od čega građa za djecu čini $39 \%$. Nabava nove građe u 2019. bila je podjednaka za djecu i odrasle, s 419 i 424 jedinica nove građe. S obzirom na to da su djeca zastupljenija među upisanim korisnicima bibliobusa, ne može se zaključiti kako se zanemaruje obnova fonda građe za odrasle. Međutim, informator I2 primjećuje da stariji i obrazovaniji korisnici ponekad imaju želje i potrebe koje nadilaze ono što fond bibliobusa nudi.

Nadalje, učenici su zadovoljniji izborom multimedije i češće ju posuđuju nego odrasli korisnici, što je očekivano uzimajući u obzir da je većina stajališta bibliobusa ispred mjesnih škola. S obzirom na to da su korisnici koji pitaju za savjete 
manje zadovoljni izborom stripova, može se pretpostaviti da se upiti ili primjedbe u najvećoj mjeri odnose na mali broj stripova i želju za novim naslovima. Iz praktičnih razloga, građu koja se rjeđe posuđuje korisnici dobivaju na upit, što obično znači da trebaju pričekati sljedeći dolazak bibliobusa.

Zanimljiva je razlika u zadovoljstvu izborom knjižne građe između starijih i mlađih korisnika u Zadru i Koprivnici. U istraživanju u Koprivnici 2009. godine među ispitanicima starijim od 15 godina bilo je $75 \%$ potpuno zadovoljnih, dok je među mlađima bilo $53 \%$ potpuno zadovoljnih. U trenutnom istraživanju korisnika bibliobusa u Zadru situacija je obrnuta, među starijima od 15 godina 53 $\%$ je potpuno zadovoljnih izborom knjiga, dok je među mlađima $94 \%$ potpuno zadovoljnih. Specifičnost ispitanika s područja Koprivnice 2009. godine bio je niži udio redovitih korisnika u mlađoj dobnoj skupini. Također, mlađi su imali izraženiju potrebu za drugim sadržajima, željeli su više igrica, filmova, ali i više novih naslova knjiga.

Na otvoreno pitanje koje se odnosilo na sugestije i prijedloge korisnika u vidu poboljšanja rada i unaprjeđenja usluga GKZD bibliobusa, samo $15 \%$ ispitanika dalo je svoje prijedloge i sugestije, što je znatno manje u odnosu na istraživanje provedeno u Koprivnici, ${ }^{36}$ gdje je čak $48 \%$ ispitanika dalo svoj prijedlog ili sugestiju, od čega najvećim dijelom ispitanici mlađi od 15 godina. U trenutnom istraživanju obrnut je slučaj, svoje prijedloge i sugestije iznijeli su uglavnom ispitanici starije životne dobi. Za usporedbu, prema istraživanju provedenom u Koprivnici ${ }^{37}$ korisnici su se po pitanju prijedloga za poboljšanje ponude također najviše založili za više novih naslova i bestselera ( $82 \%$ ), zatim za više građe koja se odnosi na lektire i stručnu literaturu (58 \%), a korisnici mlađi od 15 godina predložili su proširenje ponude bibliobusa multimedijalnom građom i računalnim igricama (18\%). Informatori Gradske knjižnice Zadar također spominju upite djece koja bi posuđivala računalne igrice, ali umjesto toga dobivaju priručnike o trenutno popularnim igrama.

\section{Zaključak}

Bibliobusne službe u Hrvatskoj prisutne su u 8 županija i u tim su sredinama već mnogo godina neizostavan dio knjižnične prakse i djelatnosti. Usluge i programi bibliobusnih službi raznovrsni su, ali prednjače radionice, igrokazi, programi za poticanje čitanja i sl. za djecu predškolske i osnovnoškolske dobi. Dosadašnja istraživanja pokazuju kako korisnici cijene značaj i ulogu pokretnih knjižnica.

Cilj ovog istraživanja bio je utvrditi informacijske i čitateljske potrebe i zadovoljstvo korisnika bibliobusa Gradske knjižnice Zadar. Tijekom ljeta 2019. godine

36 Usp. Vugrinec, Lj. Nav. dj., str. 16-17.

37 Isto, str. 17. 
provedeno je anketiranje 100 korisnika bibliobusa, stanovnika otoka i priobalja Zadarske županije. Kako bi se detaljnije objasnili rezultati i kontekst rada bibliobusa, dodatno su tijekom ljeta 2020. godine provedeni intervjui s dva knjižničara - informatora. Potrebe i interesi korisnika analizirani su na temelju prikupljenih odgovora o korištenju postojeće knjižnične građe i na temelju slobodnih komentara ispitanika. Pritom su utvrđene specifičnosti pojedinih skupina korisnika, s obzirom na radni status, dob i spol. Nadalje, rezultati analize razlika u zadovoljstvu uslugama i izborom građe omogućuju unaprjeđenje postojećih usluga.

Među korisnicima bibliobusa visoko su zastupljeni učenici. Naime, učenicima je omogućen besplatan upis, a većina je stajališta bibliobusa ispred mjesnih škola u jutarnjim satima. Također, usluga posudbe novina $\mathrm{i}$ časopisa manje se koristi nego u središnjoj knjižnici, zbog ograničenog vremena stajanja bibliobusa i ograničenog prostora za čitanje i listanje te građe.

Bibliobus Gradske knjižnice Zadar ima redovite korisnike. Korisnici uvjerljivo najviše koriste usluge bibliobusa za posudbu knjiga, dok nešto manje posuđuju multimedijalnu građu, slikovnice i stripove. Po tematici, očekivano, najviše se posuđuje beletristika, zatim literatura za djecu i zabava, dok u manjoj mjeri biografije, teme iz psihologije, zdravlja, duhovnosti, politike, sporta i stručna literatura.

Pregled rezultata s obzirom na sociodemografske pokazatelje otkriva kako među korisnicima bibliobusa postoje dvije glavne skupine korisnika: učenici i odrasli korisnici. Naime, umirovljenici i zaposlene osobe u analiziranom uzorku imaju slične čitateljske navike. Pokazalo se da učenici više posuđuju multimediju, zabavne knjige i knjige o sportu, dok odrasli posuđuju beletristiku i popularnu publicistiku te slikovnice za svoju mlađu djecu. Literaturu za djecu posuđuju djeca i dio odraslih, vjerojatno za svoju djecu i unuke. Uočene su tek manje razlike u korištenju bibliobusa s obzirom na spol. Ispitanice manje nego ispitanici listaju novine i časopise te manje posuđuju knjige koje se tematikom odnose na politiku. Ta se građa općenito malo koristi.

Općenito, korisnici su izrazito zadovoljni uslugama koje im pruža bibliobus, ponajviše uslugom djelatnika. Najmanje su zadovoljni radionicama, s tim da su ipak u prosjeku uglavnom zadovoljni navedenom uslugom. Međutim, kvalitetu radionica vrednovali su i ispitanici koji ih zapravo nisu ni pohađali, pa taj dio rezultata nije vjerodostojan.

Pojedini su korisnici manje zadovoljni izborom stripova i vjerojatno zbog toga češće pitaju knjižničare za informacije o građi. Informatori su objasnili kako u bibliobusu nema dovoljno mjesta za svu građu, pa se nakon upita korisnika pri sljedećem obilasku stajališta donese traženi naslov. Najviše se posuđuje beletristika, a korisnici koji ju posuđuju više traže savjete knjižničara. Odrasli korisnici posuđuju beletristiku te, za razliku od učenika, nisu u potpunosti zadovoljni izborom knjiga. Općenito, mlađi korisnici zadovoljniji su izborom svih vrsta građe. Učenici su 
potpuno zadovoljni izborom knjiga i multimedije, dok su odrasli korisnici nešto manje zadovoljni. Ipak, u prosjeku su uglavnom zadovoljni. Knjižničari - informatori objasnili su kako se multimedija iz središnje knjižnice ne može posuđivati u bibliobusu zbog kraćeg roka posudbe.

Informacije o novim naslovima korisnici dobivaju upitom knjižničaru, samostalno putem praćenja televizijskih emisija, portala i društvenih mreža te putem preporuka prijatelja.

$\mathrm{Na}$ temelju povratnih informacija korisnika postoji mogućnost poboljšanja usluga bibliobusa, a to se ponajprije odnosi na širi izbor knjiga i nabavu novijih izdanja domaćih i stranih autora. Tek manji broj ispitanika nezadovoljan je rasporedom knjiga na policama u bibliobusu i zahtijevaju duži ostanak na stajalištu. Također, rad bibliobusne službe uvelike bi olakšalo uvođenje klima uređaja i pouzdan pristup internetu. Dodatna moguća unaprjeđenja usluga jesu ukidanje naplate rezervacije građe te produženje roka posudbe knjižne građe. Uslijed pandemije COVID-19 uvedena je mogućnost telefonske narudžbe građe unaprijed. Međutim, posudba građe koja ne pripada fondu bibliobusa posuđuje se prema pravilima posudbe u središnjoj knjižnici: zadržavanje knjižne građe 20 umjesto 30 dana te vrlo kratak rok posudbe multimedijalne građe, što znači da korisnici moraju vratiti građu osobno u središnju knjižnicu. Moguća su kompromisna rješenja, primjerice dulji rok posudbe zvučne, vizualne i elektroničke građe, ali za manji broj jedinica građe.

Može se zaključiti kako je provedeno istraživanje potvrdilo nezamjenjivu ulogu bibliobusa Gradske knjižnice Zadar u pogledu pružanja usluga i informacija stanovnicima u najudaljenijim mjestima Zadarske županije, s nadom da će i u budućnosti nastaviti s odličnim radom te da će nastaviti „osluškivati“ potrebe korisnika i sukladno tome raditi na unaprjeđenju usluga za dobrobit svih korisnika.

\section{LITERATURA}

Črnjar, Lj.; J. Alić-Tadić; I. Čermelj. Primjena modela županijske bibliobusne službe na primjeru Primorsko-goranske županije. // Vjesnik bibliotekara Hrvatske 50, 3(2007), 54-63.

Črnjar, Lj.; Lj. Vugrinec. Pokretne knjižnice u Hrvatskoj : pogled iz prošlosti u budućnost. // Pokretne knjižnice u Hrvatskoj / uredile Ljiljana Vugrinec, Ljiljana Črnjar i Frida Bišćan. Zagreb: Hrvatsko knjižničarsko društvo; Karlovac: Gradska knjižnica „Ivan Goran Kovačić“, 2012. Str. 9-29.

Gradska i sveučilišna knjižnica Osijek: GISKO. [citirano: 2020-10-03]. Dostupno na: https://www.gskos.unios.hr/index.php/povijest-knjiznice-2/. 
Gradska knjižnica Zadar. [citirano: 2019-08-01]. Dostupno na: http://www.gkzd.hr/bibliobus

Gradska knjižnica Zadar. Godišnje izvješće 2008. Zadar: Gradska knjižnica Zadar, 2008. [citirano: 2020-10-15]. Dostupno na: https://www.gkzd.hr/pdf/dokumenti/izvjesce_2008.pdf

Gradska knjižnica Zadar. Godišnje izvješće Gradske knjižnice Zadar za 2014. godinu. Zadar: Gradska knjižnica Zadar, 2015. [citirano: 2019-08-01]. Dostupno na: https:// www.gkzd.hr/sites/default/files/gi_2014_w.pdf

Gradska knjižnica Zadar. Izvješće o radu Matične službe za 2019. g. (narodne knjižnice). [citirano 2020-08-10]. Dostupno na: https://www.gkzd.hr/maticna_sluzba

Juric, M. Istraživanja čitateljskih navika i informacijskih potreba građana Hrvatske: kratki pregled rezultata. // Hrčak, 46-47(2012), 4-5.

Knjižnice u 2019. // Državni zavod za statistiku. [citirano: 2020-10-16]. Dostupno na: https://www.dzs.hr/Hrv_Eng/publication/2020/08-03-01_01_2020.htm

Masar, M. Gradska knjižnica Zadar: 1949.-2019. Zadar: Gradska knjižnica Zadar, 2009.

Pavlović, M. Informacijske potrebe korisnika bibliobusa Gradske knjižnice Zadar: diplomski rad. Zadar: Sveučilište, 2020. Dostupno i na: https://urn.nsk.hr/urn:nbn:hr:162:969388 [citirano 2020-11-05].

Pezer, I.; Lj. Vugrinec. Pokretne knjižnice kao dio knjižnične mreže narodnih knjižnica u Hrvatskoj : stanje i razvojni planovi. // Vjesnik bibliotekara Hrvatske 58, 1-2(2015), 221-240.

Radman, N. Bibliobusna služba Gradske knjižnice Zadar. // Pokretne knjižnice u Hrvatskoj / uredile Ljiljana Vugrinec, Ljiljana Črnjar i Frida Bišćan. Zagreb. Hrvatsko knjižničarsko društvo; Karlovac: Gradska knjižnica „Ivan Goran Kovačićc, 2012. Str. 117-128.

Smjernice za pokretne knjižnice / prerađeno izdanje priredila radna skupina IFLA-ine Sekcije za narodne knjižnice na čelu s Ianom Stringerom; [s engleskog prevela Sanja Kovačević; stručna redakcija prijevoda Ljiljana Črnjar, Ljiljana Vugrinec]. 1. hrvatsko izd. (prema 2. prerađenom izd. izvornika). Zagreb: Hrvatsko knjižničarsko društvo, 2011.

Standardi za narodne knjižnice u Republici Hrvatskoj. // Narodne novine 58, 1071(1999). [citirano: 2019-09-22]. Dostupno na: https://narodne-novine.nn.hr/clanci/sluzbeni/1999_06_58_1071.html

Stričević, I.; S. Jelušić. Informacijske potrebe i čitateljski interesi građana Hrvatske. // Međunarodni interdisciplinarni stručni skup Knjiga i slobodno vrijeme: zbornik radova / uredile Elli Pecotić, Snježana Buczkowska i Katarina Krolo Žužul. Split: Gradska knjižnica Marka Marulića, 2011. Str. 16-31.

Vugrinec, Lj. Istraživanje o zadovoljstvu korisnika uslugama bibliobusa. // Svezak, 12(2010), 15-17. 
Vjesnik bibliotekara Hrvatske 63, 1-2(2020), 309-336

Zdravković, Ž.; V. Barada. Anketno istraživanje zadovoljstva korisnika/ca Gradske knjižnice Zadar. [citirano: 2019-10-18]. Dostupno na: http://www.gkzd.hr/pdf/dokumenti/GKZD_Anketa_Izvjestaj2009.pdf 